\title{
$P-157$ 形状記憶合金を用いた人工尿道括約筋の検討
}

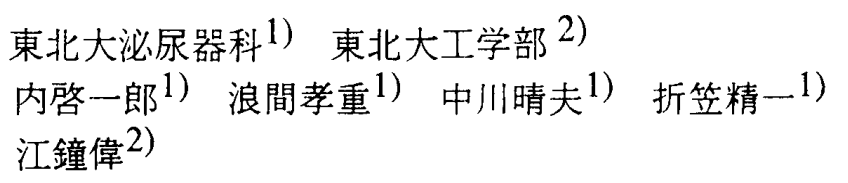

形状記憶合金を医療分野に応用する試みは1970年代の後半から米国を中心に進められ これまでの研究報告によりTi-Ni形状記憶合金の生体適合性は生体インプラント用金属材 料であるステンレス鋼、Co-Cr合金と同程度以上と判断されている。当教室ではすでに形 状記憶合金を用いた尿道ステントを実用化している。今回、尿失禁の治療法の一環として 人工尿道括約筋機構に形状記憶合金を導入し、尿道開閉用人工バルブの開発を行ったので、 これまでに得られた結果を報告する。まず膀胼、尿道の模擬モデルを用いて人工バルブの 特性を測定し、その効果を検討した。膀脱モデルとして尿道部に一定圧 $70 \mathrm{cmH}_{2} \mathrm{O}$ 付加 する水容器を設け、尿道モデルとして内径 $6 \mathrm{~mm}$ ・外径 $8 \mathrm{~mm}$ のシリコンチューブを使用した。 シリコンチューブに人エバルブを装着し実験をおこなったところ、バイアスばねを併用す ることにより室温時での流れを完全に閉鎖する事ができた。この状態で人エバルブを加熱

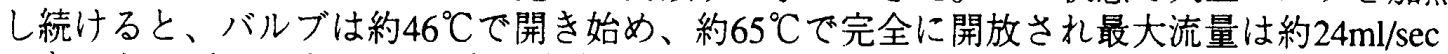
であった。更に、人工バルブを雄成犬の球部尿道に装着しバルブの特性を測定した。チュー ブを膀胱より尿道に挿入し、その先端を人工バルブの中枢側に固定し $70 \mathrm{cmH}_{2} \mathrm{O}$ の圧を付 加した。バイアスばねを併用することにより室温時での流れを完全に閉鎖する事ができた。

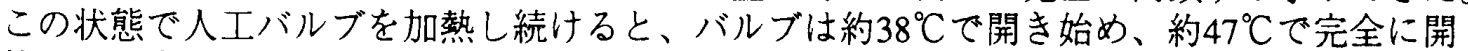

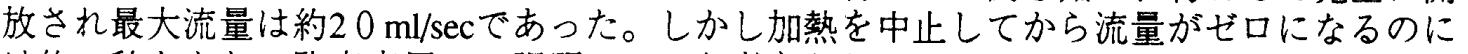
は約30秒かかり、臨床応用への課題の一つと考えられた。

\section{$P-158$}

\section{ラット実锠モアルにおける Gracilis Muscle Dynamic Urethral Sphincter Myoplasty の湌討}

Department of Urology, Thomas Jefferson University ${ }^{1}$, 岡山大学泌泳器科 2)

Toyohiko Watanabe 1), Michael B Chancellor 1), David A Rivas ${ }^{1)}$,

公文裕已 2)，大森弘之2)

【日的】㽷道括的筋不全による尿失禁に対する治療として，尿道スリング手術，尿道粘膜コラーゲン注入法， 人「原道括称筋埋設術が行われているが，難治症例には必ずしも充分な効果を挙げているとは言えない。そこ で我々はラット実験モデルによる Gracilis muscle dynamic urethroplastyについて検討した。【对象と方法】 female Sprague-Dawley ラットを用い, myoplasty 群 (M 群)， sham 群（S 群）の2 群で検討した。M群で は，一側の大腿内側より gracilis muscleを神経血管を温存したまま遊離し，尿道周囲に $360^{\circ}$ 巻きつ㚈，対側 䎵骨に固定した。 $\mathrm{S}$ 群では下腹部, 大腿部の切開のみ行った。耑群とも術後 4 週目の運動能力, 24 時間排沝パ ターン, gracilis muscleの血流状態の評価を行った。また, $18 \mathrm{G}$ 針を膀胱に留置し，生食を $0.5 \mathrm{ml} / \mathrm{min}$ で注 入し leak point bladder pressure(LPP), leak point bladder volume(LPV)を 2 群間で比較した。さらに, M 群 では gracilis muscleに対し電気刺激を加え，刺激中の LPP および LPVも測定した。【結果㧍よび考察】術後 4 调目の速動能力，24 時開排示パターンに雨群間で差は認められなかった。また，LPP，LPVの検行結果は表 に示した通りであった。

\begin{tabular}{lccc}
\hline & $\mathrm{S}$ 群 & $\mathrm{M}$ 群 (刺激一) & $\mathrm{M}$ 群 (刺激+) \\
\hline $\mathrm{LPP}(\mathrm{mmHg})$ & $28 \pm 8$ & $32 \pm 12$ & $85 \pm 27^{*}$ \\
$\mathrm{LPV}(\mathrm{ml})$ & $0.5 \pm 0.2$ & $0.6 \pm 0.3$ & $1.2 \pm 0.6^{*}$ \\
\hline
\end{tabular}

これらの基礎的検詩より Gracilis Muscle Dynamic Urethroplastyは，尿道括䄪筋不全による尿失禁㫌例に 対し臨床伈用可能であると考えられる。 